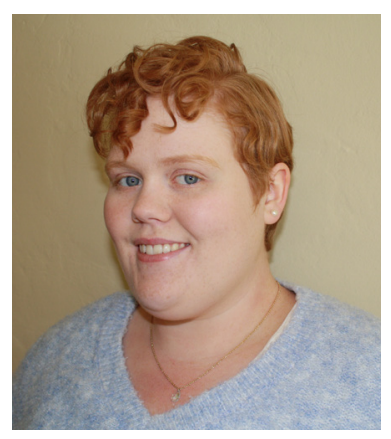

EMILY J. GAUNT is a graduating Political Science major in Spring 2016 with a concentration in Global Politics. After graduating, she plans to take a year off to travel to places such as Alaska with her family. When her year of exploration is up, she plans to buckle down to obtain her masters degree in International Relations. Emily's inspiration for this paper spurred from an eye-opening 60 Minutes story, "The Battle Above." She found the realities discussed in the 60 Minutes special as the perfect convergence of her fascinations with space and global politics. 


\title{
NEW AND CHANGING IMPLICATIONS OF EXPLORING THE FINAL FRONTIER: WHAT DOES U.S. DOMINANCE SIGNIFY FOR GLOBAL POLITICS?
}

Emily J. Gaunt

\begin{abstract}
The rapid boom in technological advances during the $20^{\text {th }}$ century transformed the dream of further space exploration from a dream to stark reality. The hostile relations of the Cold War that spurred the so-called "space race" gave way to international cooperation in space investigation. However, the cooperative tone experienced over the past few decades is not entirely indicative of the global political landscape. International space relations are still developing, as is the international space law. Without any formal authority over the regulation of space ventures, the possibility of dissension remains. This paper explores the potential for international conflict over the resources, control, and even military presence in outer space. The United States' dominance as the acting authority over outer space enterprises will result in a great impact global politics in both the near and distant future.
\end{abstract}




\section{Real World Observation}

On April 17, 2015, the $31^{\text {st }}$ annual Space Symposium was held in Colorado Springs, Colorado, at which, the secretary of the Air Force, Deborah Lee James, spoke about the importance of space utilization as well as maintaining U.S. dominance in the area of space technology. ${ }^{1}$ According to the Official Air Force Space Command website, the Secretary stated outright on the issue of competition in space that "the United States of America working shoulder to shoulder with our allies and partners, will not be bested." ${ }^{2}$ Secretary James discussed the top three issues that impact the future of the space domain. One of the Secretary's main priorities involves spreading awareness about the importance of space in everyday functioning, including satellite communications and international banking. The second point concerns the rapidly changing space environment. Outer space faces new threats such as excessive amounts of space debris, as well as the potential for hostile actions from competing nations through the use of anti-satellite technology, namely from China. Lastly, the secretary spoke about the importance of being prepared for the day that space is no longer a peaceful resource. ${ }^{3}$ The Secretary's message was clear, the United States will not relinquish any power from the domain of space. U.S. officials are adamant that military strategies must be adjusted to the demands of the political atmosphere of space.

Since the time of the initial Space Race during the Cold War, competing nations have had to interact in an under-regulated space, but U.S. dominance has always been present. Although there are several international treaties declaring the rights and responsibilities of countries, namely the requirement of the peaceful use of outer space, much activity is under the honor system of conduct. ${ }^{4}$ The lack of international regulation in outer space, combined with increased interest in space development, will likely have far-reaching implications here on earth. Many of the new areas of space remain unresolved areas of disagreement, including the advancement of profitable enterprises in outer space. Examples of the commercialization

\footnotetext{
${ }^{1}$ Tech. Sgt. Mike Slater, "Secretary of the Air Force James delivers message of confidence," Air Force Space Command Public Affairs (April 17, 2015).

${ }^{2}$ Ibid.

3 Ibid.

${ }^{4}$ Benjamin Soloway, "Lawyers In Space," Foreign Policy (April 15, 2015).
} 
of space involve tourism and asteroid mining. Soon, companies will offer commercial flights into space, provided that passengers are willing to pay a hefty fee. ${ }^{5}$ The possibility for conflict over space enterprises could become a reality faster that anyone can imagine. The United States is one step closer to preparing for a war in space, as illustrated by the insistence on defensive space technologies. The United States government simultaneously asserts dominance and claims space is a global utility. What many once thought was science fiction is now becoming a scientific reality.

Space has become the newest market of expansion and governments, as well as private companies, are changing the way the world looks at what was once declared a peaceful resource of shared human culture. ${ }^{6}$ Today, as countries continue to expand the knowledge of space and the benefits that earth can earn from expanding to the stars, nations are now required to interact in new ways that reflect modern interests. The scenarios that the U.S. presents are mostly hypothetical right now, aside from Chinese attempts at anti-satellite technology, but the possibility that conflict could occur over resources or access to satellites is a growing concern. The lack of international regulation in outer space could make this new era of space exploration a volatile one. This research argues that the U.S. will continue to maintain a unipolar space and seeks to explore the impact this dominance will have on global politics in the $21^{\text {st }}$ century.

\section{Conventional Wisdom}

It is the conventional wisdom that space is a peaceful resource for mankind to share as opposed to a potential conflict area. Generally, Americans are optimistic about the use and exploration of space. While the age of initial exploration into outer space was deemed a race during the Cold War, it was almost always considered to be a peaceful endeavor that could one-day benefit mankind. A Gallup poll from 2004 on the issue of public support for the space program reflects the conventional wisdom of space as a peaceful resource. In 2004, 67\% of Americans had at least some interest in the space

\footnotetext{
5 Alan Boyle, "After Accident, Virgin Galactic Takes a Cautious Path to Spaceflight," NBC

News (March 31, 2015).

6 Soloway, "Lawyers In Space."
} 
program and space exploration. ${ }^{7}$ The poll confirmed that most Americans believe that space should be a peaceful enterprise. When asked why they think governments explore space, most Americans believe it is for knowledge, global reputation as a leader in space, or that it benefits earth in some way. A mere $12 \%$ responded that the reason is "keeping the nation safe," by using space as some sort of defensive tactic. ${ }^{8}$ In a poll by the Pew Research Center in 2014, it was reported that the majority of Americans supported space travel and international cooperation of a space program. The support for technological advancement is overwhelming, with most Americans saying that these developments "will have a net positive impact on society" while $59 \%$ believe that innovations will improve the quality of life in the future. ${ }^{9}$ The conventional wisdom on the exploration of space and the advancement of technology is overwhelmingly positive and most of the public thinks of space as a beneficial resource for the world to share, not as a source of conflict in global politics.

The conventional wisdom concerning the advancement of space exploration and its implications on international relations is incomplete. Currently, the international community continues to cooperate in outer space. The expansion of space enterprises, however, presents opportunities for both growth and conflict. Ownership of mining resources, commercial space flight, and control over satellites are all areas of potential conflict. These new areas of conflict in outer space are missing from the conventional wisdom. It is the impact of these conflict areas, including satellites, resources, and the development of weapons, on global politics that this research explores.

\section{Theoretical Paradigm}

To investigate these conflict areas, this paper uses the theory of realism. Realism helps to explain and frame this research due to the theory's assumptions about the relative power of states being the primary cause of change in international politics. As realists assume that human nature is conflictual, the process by which space will become the new war zone can

\footnotetext{
7 Darren Carlson, "Space: To Infinity and Beyond on a Budget," Gallup (August 17, 2004).

8 Ibid.

9 Aaron Smith, "U.S. Views of Technology and the Future," Pew Research Center (April 17, 2014).
} 
be explained using principles of realism. As anarchy is the guiding force in global politics, international legal relations reflect the self-interest of states. These same principles can be applied to the utilization and expansion of space technologies. Though the United States is claiming that its system of satellites is a global utility, the government is ensuring that the control and benefits remain the right of the U.S.

The United States' insistence on remaining the only real power in outer space is reflective of the realist notions of state-centered interests. The U.S. is acting in such a way that reflects realist principles of international relations. By definition, realist countries cannot trust another nation. By stating that U.S. dominance will not be relinquished and demonstrating that the government has the ability to defend itself if need be, the United States is illustrating realism in action. The U.S. also understands that in asserting their dominance in space, a zero-sum game is being played, in which there will likely be multiple losers. Realist principles of self-interest set the stage for the U.S. to demand ownership of any resource found in space, which includes unique mining opportunities of rare materials from asteroids.

The conventional wisdom is better aligned with liberalism, and proponents would argue that the International Space Station (ISS) is evidence that the international community is capable of cooperation in space. However, most states have been shown to follow the realist pattern of behavior in international relations more so than expected liberal patterns. The driving force behind the initial exploration into space was conflict. Now that space technology has become essential to daily operations on earth, states will begin to wrestle with others over the possibility of gaining power at the level of outer space. Nations have already begun looking for chinks in the armor of the United States' technology in space. Recent testing of anti-satellite missiles indicates that the world may soon experience a higher form of warfare only seen before in fictional accounts of the future.

\section{U.S. Dominance Over Control of Satellites}

According to a 60 Minutes piece from April 26, 2015, the United States military is preparing for a potential all-out war in space. ${ }^{10}$ Much of the world relies on satellites for communication and Internet access, but the United

${ }^{10}$ David Martin, host, Andy Court, producer, "The Battle Above," 60 Minutes, CBS News (April 26, 2015). 
States in particular depends on satellites for national defense and military missions. The 60 Minutes script states that there is a new concern that vital "satellites are vulnerable to attack" from anti-satellite missiles, namely from China and Russia. ${ }^{11}$ The report from 60 Minutes claims that China has launched several anti-satellite missiles, creating U.S. concern. In 2007, a Chinese missile hit a Chinese satellite and created enormous amounts of space debris, which added about 3,000 pieces to the growing collection. ${ }^{12}$ According to NASA, there are over 500,000 pieces of space debris that are currently being tracked. ${ }^{13}$ Both man-made objects and naturally occurring objects, such as meteors, are considered debris. A single piece of rubble, traveling at over $17,000 \mathrm{mph}$, has the potential to do significant damage if it collides with satellites or spacecraft. ${ }^{14}$ In 2013, another Chinese anti-satellite missile reached an unprecedented height for such technology. Both China and Russia have been testing anti-satellite capabilities for decades. It is the occurrences of these tests that are motivating the U.S. military to reassert their dominance for the world to see in order to maintain a unipolar space. ${ }^{15}$ General Hyten, a military official interviewed by 60 Minutes, is clear that his mission allows for the use of force in the "defense" of space. The U.S. military can and will use military force to continue its reign in space.

The largely unknown branch of the U.S. Air Force known as Space Command is in charge of monitoring threats and preparing to respond to the potential for a war in space. According to General John Hyten of Space Command, the United States military relies heavily upon space technology, particularly satellites, to operate. The U.S. military has over 500 satellites and spends more than $\$ 25$ billion on space annually and will only continue to expand its capabilities. The actual costs of the program, however, continue to be difficult to pin down. ${ }^{16} \mathrm{~A}$ report from the Government Accountability Office on government funding found that between 2014 and 2018, the U.S. government will spend approximately $\$ 44$ billion on launch related

\footnotetext{
11 Ibid.

12 Ibid.

13 Mark Garcia, "Space Debris and Human Spacecraft," NASA. (September 26, 2013).

${ }^{14}$ Ibid.

15 David Martin, host, Andy Court, producer, "The Battle Above.”

16 Ibid.
} 
activities alone. ${ }^{17}$ While the U.S. frames its satellite system as a global utility, the message that the Air Force wishes to put forth is clear, the U.S. controls that utility as they see fit. The U.S. government has strategically designed its position of dominance in space technology. The existence of programs like space command implicates that governments are preparing for a new form of warfare. As General Hyten declared himself, Space Command is "not NASA" and the purpose of the military is to use force. Through the preparations to defend space, the U.S. may be creating its own self-fulfilling prophecy.

As early as 1997, the United States Air Force Space Command has seen the need for a long-range plan to ensure U.S. dominance. A report published by Space Command entitled "Vision for 2020" describes this plan. ${ }^{18}$ The report begins with an explanation of Space Command's mission to dominate military operations in outer space in order to preserve U.S. interests "by integrating space forces into war fighting capabilities across the full spectrum of conflict." ${ }^{19}$ The report illustrates the evolution of warfare and technology to explain how the military has risen to the occasion of land, sea and air threats and is now tasked with responding to the economic and military interests in space. The report refers to space as "the fourth medium of warfare," implicating the U.S. is preparing for combat in space. ${ }^{20}$ The report also details how the U.S. will attain what the report calls "Full Spectrum Dominance" in an effort to deny any adversaries' attempt to gather information, as the military depends on space technology for communications and remaining the eminent leader in gathering intel. ${ }^{21}$ Full spectrum dominance entails "concepts of dominant maneuver, precision engagement, full-dimensional protection, and focused logistics" in order to maintain space dominance and protect American interest in space. ${ }^{22}$

By 2010, Space Command expected to attain this dominance in order

17 Carl Levin, John McCain, Committee on Homeland Security and Governmental Affairs, "Space: Defense and Civilian Agencies Request Significant Funding for Launch-Related

Activities," United States Government Accountability Office, (September 9, 2013).

${ }_{18}$ Howell M. Estes, General USAF Commander In Chief, "United States Space Command

Vision For 2020," (February 1997).

19 Ibid.

${ }^{20}$ Ibid.

${ }^{21}$ Ibid.

22 Ibid. 
to gather information during peacetime, deter any sort of conflict, and ultimately be able to win any sort of conflict in space. The report accurately predicted that the future of technological developments would occur largely in the private sector, and anticipated that this shift would contribute to the widening wealth gap associated with globalization. The importance of space enterprises in the global economy is prioritized. This that concern over space technologies being attacked exists. To minimize the threat to space resources, military strategy has been adapted to the new trends in space development. ${ }^{23}$ The overall theme of the report is that space superiority is essential as the world becomes increasingly dependent upon satellites. The ability to maintain dominance as the global space power is the vision of Space Command and has been its mission since the 90 s.

The Department of Defense issued a press release on January 7, 2014 emphasizing the importance of space defense as an asset to the day-to-day functioning of military and civilian lives. ${ }^{24}$ General William Shelton of Space Command spoke of the concern over the threat to necessary satellites to students at George Washington University. General Shelton stated that although space technology provides the opportunity to prevent and aid in disasters around the world, societies' dependence on successful satellite operation presents new challenges for the military in the $21^{\text {st }}$ century. ${ }^{25}$ His main concern is that opponents are rapidly approaching the day when they can challenge U.S. dominance. General Shelton insists that military strategy must change to anticipate threats. Emphasizing that new crucial satellite construction must stay ahead of other nations. Additionally, the military should aim to complicate the targeting systems of competing forces. ${ }^{26}$

The evidence presented in this case study illustrates the United States' dominance over the control of space could create conflict on the world stage. The U.S. military has issued reports on their impression of the threats that space faces as well as the defense procedures necessary for protection. The insistence on U.S. dominance in space technology is reflective of realist

\footnotetext{
${ }^{23}$ Ibid.

${ }^{24}$ Jim Garamone, "Shelton Discusses Importance of Space Defense," Department of Defense American Forces Press Service, (January 7, 2014).

25 Ibid.

${ }^{26}$ Ibid.
} 
principles of state actions. ${ }^{27}$ Nations must now figure out what their reaction to this U.S. assertion in space dominance will be. The U.S. has been instituting its dominance for several decades, and now wants the world to comprehend that the U.S. military will defend its position as the world leader in space ventures. The sector of outer space is now at the forefront of global politics, and the U.S. is attempting to maintain the similar unipolar system that it currently has on earth. As nations develop new technologies, global politics will be impacted by the possibility of the fight over the control of valuable space enterprises.

\section{Conflict Over Resources}

The world constantly struggles to agree on the distribution of resources, such as food, water and precious products. With dwindling supplies of non-renewable resources, humanity is looking for new possibilities. The possibility that nations will begin to look at outer space for resources signifies another area for conflict in global politics as humankind moves into the twenty-first century. There are several different opportunities to seize as far as space resources go, including rare and valuable materials, expansion of agriculture and possibilities for new territories. For years, the human race has toyed with the idea of colonizing another planet and now science is starting to catch up with humanity's propensity for expansion. Private companies are now offering commercial flights into space, the price tag of which illustrates that space opportunities are not going to benefit all nations, but simply those with enough wealth. ${ }^{28}$

The ISS represents humanity's first steps toward colonizing space, in addition to earlier launches of manned rockets and the moon landings. Many believe that the ISS is just the beginning of the colonization of space. ${ }^{29}$ For more than twenty years, NASA has held the NASA Ames Space Settlement Contest for students under the age of eighteen to design a colony for humans to inhabit space. ${ }^{30}$ While this competition directly states that any design must

\footnotetext{
${ }^{27}$ Tech. Sgt. Mike Slater, "Secretary of the Air Force James delivers message of confidence."

${ }^{28}$ Boyle, "After Accident, Virgin Galactic Takes a Cautious Path to Spaceflight."

29 W. H. Siegfried, "Space Colonization-Benefits for the World," Space Technology and Applications International Forum, vol. 654, (February 2, 2003): 1270-1278.

${ }^{30}$ Al Globus, "NASA Ames Space Settlement Contest,” NASA.gov, (June 9, 2015).
} 
not be on any specific planet or space body, it involves a plan for humans to leave earth and live in a new space age with cutting-edge technology. According to the competition's web page, the result of mining one asteroid for materials "can build space colonies with living space equal to about 500 times the surface area of the Earth." ${ }^{11}$ This statement signifies that colonizing planets could be made possible with mining asteroids of valuable material. With further advancement of technology and motivation to leave what some fear is a dying earth, humans may be closer to colonizing space than solving the climate and population problems that earth faces.

While the potential for actually colonizing space may yet be several years off, the reality of space mining is not far off at all and is currently a major debate on the global stage. On May 22, 2015, the United States House of Representatives passed the SPACE Act a bill that gives businesses the right to any material that is mined out of asteroids. ${ }^{32}$ At this point, no company has actually announced realistic plans to mine asteroids, but the possibility has been floating around for years and the international community is faced with the issues of space commercialization. ${ }^{33}$ For a while now, the U.S. has been advocating for the ownership of mining resources in space to belong to the company that extracted them and the passage of the property rights bill signifies the transition from talking about the possibility of mining to a step forward in actual commercial space exploitation. ${ }^{34}$ Although the SPACE Act is concerning the privatization of asteroid mining resources, it still shows how the U.S. is grasping onto much of its power and even gaining more. The United States government has long endorsed the privatization of space as it frees up the federal budget for things like military space defense, which will ensure a stable market for American companies who work closely with government agencies..$^{35} 36$

\footnotetext{
31 Ibid.

32 Brian Fung, "The House just passed a bill about space mining. The future is here," Washington Post (May 22, 2015).

33 Soloway, "Lawyers In Space."

${ }^{34}$ Fung, "The House just passed a bill about space mining. The future is here."

35 Ibid.

${ }^{36}$ Estes, General USAF Commander In Chief, "United States Space Command Vision For 2020."
} 
Mining asteroids for valuable material is no new concept, but technology has now reached a point where mining is an actual possibility. Asteroid mining can be done in a variety of ways and could provide the earth with valuable materials that nations now desperately need. ${ }^{37}$ These materials include platinum, a precious metal used in electronics, palladium, which has a similar range of uses as platinum, and the highly useful resource of water. Asteroid mining could occur several different ways from onsite robotic extraction methods to towing and retrieval methods. ${ }^{38}$ Companies have long been working up ideas to mine near earth asteroids and now the technology to mine deep space asteroids is also becoming a reality. ${ }^{39}$ These companies include Deep Space Industries, Planetary Resources, and Bigelow Aerospace, all of which are eager to explore all that commercialized space has to offer, including space tourism and mining ventures. ${ }^{40}$

Passing the SPACE Act ensures that control over revenue from space mining practices remains partially in the hands of the United States. However, this bill is not mean that international organizations accept these property rights. International law on the ownership rights of mining resources does not yet exist and asteroid mining is still hypothetical. ${ }^{41}$ The passage of the SPACE Act signifies that the United States has both the intent and capacity to begin exploiting space resources for all that they are worth. A Department of Defense report from 2001 lays out the objectives for the future of the United States' involvement in space. The detailed report calls for an adequate understanding of the transforming way that space is used. ${ }^{42}$ One of the most important areas that the report stresses is the necessity to develop new technologies to maintain superiority and foresee threats and emerging industries. In order to accomplish this task, the U.S. would need "a healthy industrial base, improved science and technology resources, an attitude of risk-taking

\footnotetext{
${ }^{37}$ Kate Tate, "How Asteroid Mining Could Work," SPACE.com, (January 22, 2013).

${ }^{38}$ Ibid.

39 Ibid.

${ }^{40}$ Ibid.

${ }^{41}$ Soloway, "Lawyers In Space."

${ }^{42}$ Department of Defense Space Commission, "Report of the Commission to Assess United States National Security Space Management and Organization Pursuant to Public Law 10665," Department of Defense, (January 11, 2001).
} 
and innovation, and government policies that support international competitiveness." ${ }^{43}$ The SPACE Act is one of the ways these goals have come to fruition. The privatization of commercial space by the U.S. has furthered a unipolar control of space. Although the mining of asteroids has the potential to help all nations and peoples, the United States has come one step closer to assuring that it will control how these resources are dispersed, echoing the insistence that the satellite network is a global utility. While the U.S. claims that both satellites and resources are a global resource, there is a sector of space that is not remotely peaceful. In violation of international treaties, the U.S. has been quietly increasing weapons technology.

\section{Development of Space Weaponry}

In addition to conflict over U.S dominance over the fields of satellites and space resources, another potential area for global dissension involves the advancement of the weaponization of space. While science fiction writers have been using space warfare as a plot device for decades, space and weapons programs have had the intent and have been trying to attain the capacity to create the required technology to prepare for the day when space is no longer peaceful. In fact, there is significant evidence that the development of space weapons has now become a scientific reality. The field of weapons development is vast and varied, and the United States has shown that it is prepared to defend itself in space. ${ }^{44}$ The range of options for defense in outer space includes ground-to-space anti-satellite missiles, such as those that the Chinese have, ground-based lasers, airborne lasers, space-based conventional weapons, ballistic missiles with nuclear capabilities and much more. ${ }^{45}$

One leader in weapons development of the twenty-first century has been the United States' Defense Advanced Research Projects Agency (DARPA). The self-described mission of DARPA is to ensure that the U.S. remains the eminent producer of defense technology. ${ }^{46}$ According to a statement by the

\footnotetext{
43 Ibid.

${ }^{44}$ David Martin, host, Andy Court, producer, "The Battle Above."

45 SPACE.com Staff, “Top 10 Space Weapons," SPACE.com, (April 5, 2013).

${ }^{46}$ Tony Tether, Dr., "Statement By Dr. Tony Tether Director Defense Advanced Research Projects Agency Submitted to the Subcommittee on Emerging Threats and Capabilities Committee on Armed Services United States Senate," Defense Advanced Research Projects Agency, (April 10, 2002).
} 
director of DARPA in 2002, submitted to the United States Senate, DARPA is involved in the continuous transformation of military efforts in space. In addition to developing more affordable launch capabilities for satellite payloads, DARPA is involved in a space surveillance and advanced warning systems to threats posed to necessary satellites, called the Satellite Protection and Warning/Space Awareness (SPAWN). ${ }^{47}$ DARPA is also working on a space weapon that has the ability to utilize "electromagnets to shoot a stream of molten metal at incredible speeds toward enemy targets." ${ }^{48}$ This program, Magneto Hydrodynamic Explosive Munition (MAHEM) "offers the potential for higher efficiency, greater control, and the ability to generate and accurately time multiple jets and fragments from a single charge." 49

While the U.S. is denying the actual weaponization of space, officials are saying one thing and doing another. In 2001, Congress attempted to pass the Space Preservation Act of 2001 in order "[to] preserve the cooperative, peaceful uses of space for the benefit of all humankind by permanently prohibiting the basing of weapons in space by the United States, and to require the President to take action to adopt and implement a world treaty banning space-based weapons." 50 The bill sought a permanent ban on the development and use of weapons in space and to "remove from space any existing space-based weapons of the United States," indicating the possibility of the existence of space weapons designed by the United States. ${ }^{51}$ The bill defined weapons as any device capable of several things, including those that collide with and destroy an object in space. The bill cited the weaponization of space as:

The use of land-based, sea-based, or space-based systems using radiation, electromagnetic, psychotronic, sonic, laser, or other energies directed at individual persons or targeted populations for the purpose of information war, mood management, or mind control of such persons or populations;

\footnotetext{
47 Ibid.

48 SPACE.com staff, "Top 10 Space Weapons."

49 Dr. Kevin Massey, "MAgneto Hydrodynamic Explosive Munition (MAHEM)," DARPA. mil, (No date).

${ }^{50}$ Dennis Kunich, $107^{\text {th }}$ Congress, "Space Preservation Act of 2001," Federation of American Scientists, October 2, 2001.
}

${ }^{51}$ Ibid. 
or by expelling chemical or biological agents in the vicinity of a person. ${ }^{52}$

However, despite the intentions of this bill, it did not pass and according to the official website of the U.S. Congress, the bill received "Unfavorable Executive Comment" from the Department of Defense on April 19, 2002.53 As of 2008, the United States openly opposed a ban on weapons in space, according to the New York Times. ${ }^{54}$ The United Nations Conference on Disarmament, held in 2008, put forth a Russian-Chinese draft of an international treaty that sought to ban weapons in space in order to prevent another Cold War-style arms race. The United States rejected the ban, stating that the treaty would impede access to space and limit its use as well as the treaties lack of enforceability. ${ }^{55}$

The United States' refusal to pass the Space Preservation act of 2001, and the refusal to support any international treaty banning the use of weapons in space signifies that the U.S. does not want any inhibitors to the research and development of space weapons. Many weapons systems here on earth can be modified to be used as a weapon in space, including ballistic missiles and DARPA's MAHEM. In addition to MAHEM and other DARPA programs, there has been much speculation about space lasers. In the 1980s, the Strategic Defense Initiative, nicknamed Star Wars, introduced the world to a new form of defensive options. An article from the journal Nature discusses the reality and future of space weapons. The article reports on a Boeing designed prototype of a laser weapon, called the High Energy Laser Mobile Demonstrator (HEL MD), as being only one of several laser weapon options being developed for the United States government. ${ }^{56}$ While laser programs initially faced setbacks from feasibility restraints, laser weapons are now moving beyond obstacles and optical fiber laser technology is rapidly becoming the go-to choice. ${ }^{57}$ Some expect that laser weapons could be put into fully operational use

\footnotetext{
52 Ibid.

${ }^{53}$ Dennis Kunich, “H.R.2977 - Space Preservation Act of 2001,” Congress.gov, (2001-2002).

${ }^{44}$ Nick Cumming-Bruce, "U.N. Weighs a Ban on Weapons in Space, but U.S. Still Objects," New York Times, February 13, 2008.

55 Ibid.

${ }^{56}$ Andy Extance, "Military technology: Laser weapons get real," Nature, May 27, 2015.

57 Ibid.
} 
for military defense in five to ten years. ${ }^{58}$ For space, this advancement means that the United States military is that much closer to establishing full dominance in all fields of space development. The U.S. continues to deny any official weaponization of space, but actions indicate a contradiction on the matter. The weaponization of space without transparency in international relations represents the final stage in achieving dominance in space technology and development.

\section{Ramifications of Findings}

The research findings implicate that the world is headed toward a new era in international interaction in space. The dominance of the United States in the areas of space technology and defense has been very publicly asserted. Competing nations, namely China, have been shown to be exploring at least the option of challenging that dominance. Technology programs all over the world have the potential to catch up and adapt to this new space age if the concerns of Space Command leaders are valid. At the very least, these concerns illustrate the changing dynamics of space as well as the potential for space to see combat. International regulation of space has proven incompetent to adequately resolve the possibility of conflict over access to space ventures and resources. Thus far, the national response from the U.S. has been to simply confirm dominance through legal action and public displays. In each area that the U.S. has asserted dominance, the potential for international conflict over the next several decades exists.

Government contracts for the development of weapons that can one day be utilized in space, combined with U.S. dominance in control over satellites operated by military forces and closely working with the privatization of space, will have significant impacts on global politics. The United States is implementing all its power to maintain full spectrum dominance and control over space technology and has shown that it has both the intent and the capacity to accomplish a unipolar space. However, this attempt at asserting dominance does not entirely deter competition. Competing nations around the world will soon possess the ability to go up against American technology, or at least begin developing programs with the intent to challenge U.S. dominance. With the competition over access to space resources, satellites, and the development of weapons in space, global leaders must acknowledge the potential for conflict in outer space.

\footnotetext{
58 Ibid.
} 